\title{
Anxiety Level, Interaction, and Family Harmony of Family Launching Stage in Bogor Regency and Bogor City
}

\author{
Wahyu Wulaningsih ${ }^{1 *}$, Diah Krisnatuti ${ }^{2}$ \\ ${ }^{1,2}$ Department of Family and Consumer Sciences, Faculty of Human Ecology, IPB University, \\ Bogor 16680, West Java, Indonesia \\ *) Corresponding author: akuwulan97@gmail.com
}

\begin{abstract}
The family of the launching stage is a family when the children start leaving home. This research aims to analyze the effect of the level of anxiety and interaction into family harmony of launching stages in the regency and city of Bogor. Respondents in this study were wives from launching stage families with 60 respondents from regency areas and city areas. Respondents were selected for purposive sampling. Data was collected through interviews, then analyzed using descriptive analysis and inferential analysis. The results showed the anxiety level of wives is in the normal category. Family interaction in the middle category. Meanwhile, family harmony in a higher category. Overall, the length of the wife's education, the duration of her husband's education, per capita income, and family interaction had a significant positive relationship with family harmony and the level of anxiety had a significant negative relationship with family harmony. This study found that husband-wife interaction and parent-child interaction has a significant effect on family harmony.
\end{abstract}

Keywords: anxiety level, family harmony, family interaction, family launching stage

\begin{abstract}
Abstrak
Keluarga launching stage merupakan keluarga saat anak mulai meninggalkan rumah. Penelitian ini bertujuan menganalisis pengaruh tingkat kecemasan dan interaksi terhadap keharmonisan keluarga launching stage di kabupaten dan kota Bogor. Responden pada penelitian ini adalah istri dari keluarga launching stage dengan jumlah 60 responden dari wilayah kabupaten dan kota. Responden dipilih secara purposive. Data dikumpulkan melalui wawancara, lalu dianalisis menggunakan uji deskriptif dan uji inferensia. Hasil penelitian menunjukkan tingkat kecemasan istri keluarga launching stage terkategori normal. Interaksi keluarga launching satge terkategori sedang. Sementara itu, keharmonisan keluarga launching stage terkategori tinggi. Lama pendidikan istri, lama pendidikan suami, pendapatan per kapita, dan interaksi keluarga memiliki hubungan positif signifikan dengan keharmonisan keluarga, dan tingkat kecemasan memiliki hubungan negatif signifikan dengan keharmonisan keluarga. Penelitian ini menemukan interaksi suami-istri dan interaksi orangtua-anak berpengaruh signifikan terhadap keharmonisan keluarga launching stage.
\end{abstract}

Kata kunci: interaksi keluarga, keharmonisan keluarga, keluarga launching stage, tingkat kecemasan 


\section{Introduction}

The progress of the nation has so far been more measured using economic indicators, such as economic growth and poverty reduction. In recent years, the progress of a nation is measured by the level of happiness. Various studies related to happiness indicate that population happiness will significantly influence the success of social development and development in society (Forgeard et al., 2011). As a developing country, Indonesia Family Happiness Index has increased from 68.28 in 2014 to 70.69 in 2017 (Badan Pusat Statistik, 2017). This indicates that the living conditions of Indonesia's population are considered quite happy.

The happiness index is compiled by several indicators. The most influential indicator in one's happiness is family harmony, which is equal to 80.05 (Badan Pusat Statistik, 2017). Family harmony is defined as a synergistic state between husband and wife with the creation of a state of mutual respect, acceptance, appreciation, trust, and love between couples so that they can carry out roles in the family with full effectiveness and inner satisfaction (Hisbullah, 2007). Family harmony is composed of communication, mutual respect, low conflict, and having free time with family (Lam et al., 2012). Family harmony cannot be automatically obtained, but efforts are needed to create a harmonious family. Efforts that can be done by families are carrying out family functions (Triniad et al., 2003), mutual respect, spending sufficient time with family, and establishing interactions between family members (Pangaribuan, 2016). Disharmony in the family can cause divorce. Most divorces do occur at a young age of marriage due to lack of preparation for marriage (Tsania, 2015), but it does not rule out divorce also occurs at the age of marriages that have entered the launching stage (first child leaving home).

At the launching stage, the husband and wife enter middle adulthood in which they start to experience a decrease in physical and psychological function. In these conditions, women will be increasingly reluctant to make physical contact with their partner, resulting in decreased harmony in couples (Setiati, 2002 in Anisa, 2018). Physical, psychological barriers and conflicts that occur between partners can inhibit interactions (Pangaribuan, 2016) and trigger general health problems or mental health such as anxiety (Annisa \& Ifdil, 2016). Thinking about the state of the child, as well as the loss of family members are internal family conditions that cause pressure in the family (McCubbin, 1988). Pressure in the family is also caused by external environmental factors, such as social and cultural conflicts, natural disasters, and resettlement (Kozier \& Erb, 1983 in Rasmun, 2004).

According to Wheatley (2014), low family interactions may result in family disharmony. Interaction is an action that occurs on two or more objects with mutual influence or has an effect on each other (Puspitawati, 2013). Interaction in the family is defined as a relationship that exists between family members in order to carry out their duties properly and involves emotional control in relationships (Waldinger \& Schulz, 2006). Good interaction can maintain a relationship and avoid conditions that damage the relationship. Conversely, unfavorable interactions will trigger family unhappiness, and can even lead to divorce (Sunarti, 2013).

The indicator to measure happiness other than harmony is feelings of anxiety. Anxiety is a form of unpleasant emotional condition, characterized by subjective feelings such as tension, fear, and worry (Beuke, Fischer, \& McDowall, 2003). Anxiety disorders 
arise as a result of the accumulation of frustration, conflict, and stress (Mu'arifah, 2005). Herry (2012) explained that prolonged stress can cause physical and emotional family crises, including disrupting relationships with other family members. Anxiety also affects health status so that it impacts on daily activities (Lestari, Wihastuti, \& Rahayu, 2013).

At present, research on harmony in the launching stage family is still relatively small, especially, if it is associated with anxiety levels. In previous studies, subjects used in the study of harmony were family farmers (Sari \& Puspitawati, 2014), families of different ethnicities (Septiana, Krisnatuti, \& Simanjuntak, 2011), and elderly families (Anisa, 2018). In addition, research on this topic documented the associations between family harmony and marital relationships (Nancy, Wismanto, \& Hastuti, 2013), family adjustment (Septiana et al., 2011), and adolescent social interactions (Yunistiati, Djalali, \& Farid, 2014). The study of the relationship between family harmony, anxiety levels, and family interactions, especially at the launching stage is still scarce.

Based on the explanation above, this study aims to 1) identify differences in family characteristics, anxiety levels, family interaction, and family harmony at the launching stage in Bogor Regency and Bogor City; 2) analyze the relationship between family characteristics, anxiety levels, family interactions, and family harmony at the launching stage in Bogor Regency and Bogor City; 3) analyze the influence of family characteristics, anxiety levels, and family interaction on family harmony at the launching stage in Bogor Regency and Bogor City.

\section{Methods}

\section{Participants}

This study was a cross-sectional study. This study was carried out in Pabuaran Village and Pabuaran Mekar Village representing Bogor Regency and Cibadak District representing Bogor City. The research location was chosen purposively with the consideration that Bogor Regency is the most populous area in West Java, while Bogor City is one of the buffer cities of the capital city of Jakarta. The study was conducted in February-May 2019. The population in this study was intact families with one child leaving home (for reasons of school, work or marriage) living in Bogor Regency and Bogor City. The study involved 60 participants consisting of 30 families in the Bogor Regency area and 30 families in the Bogor City area. The sampling was carried out using the purposive sampling method.

\section{Measures}

The collected data were primary data and secondary data. Primary data were obtained through interviews using questionnaires consisting of family characteristics, anxiety levels, family interactions, and family harmony. Secondary data included population data and related literature studies. Family characteristics were composed of wife's age, husband's age, wife's education length, husband's education length, wife's occupation, husband's occupation, family's per capita income, and family size. The age was divided into three categories (Hurlock, 1980): early adulthood (18-40 years), middle adulthood (41-60 years), and late adulthood (>60 years). The length of education consisted 
of six categories: (1) 0 years, (2) <6 years, (3) 6 years, (4) 7-9 years, (5) 10-12 years, (6) > 12 years. The job consisted of (1) no paid job, (2) farmers, (3) traders, (4) labor, (5) Civil Servants/Army/Police, (6) entrepreneurs, and (7) others. Family per capita income was divided into two categories: poor and non-poor, based on the 2017 Bogor poverty line in the amount of Rp450,078 and the 2017 Bogor Regency poverty line in the amount of Rp337,550. Based on the number of family members, the family size was divided into three categories (Badan Kependudukan dan Keluarga Berencana Nasional, 2005): small families ( $<4$ people), medium families (5-7 people) and large families ( $\geq 8$ people).

The anxiety level was measured using the Zung Self Rating Anxiety Scale (ZRAS) (Zung 1971) which has been modified by the researchers consisting of 18 statements with a 4-point Likert scale (1=never, 2=sometimes, 3=often, 4=always). The Cronbach's alpha value of this instrument was 0.760 . The composite score was categorized as normal (25$40)$, mild (40.01-55), moderate (55.01-70), severe (70.01-85), and very severe (85.01-100) (Lovibond \& Lovibond, 1995). The family interaction consisted of husband-wife interactions and parent-child interactions. It was measured using an instrument by Chuang (2005) that has been modified by the researchers consisting of 24 statements of marital interactions and 20 statements of parent-child interaction. The items of family interactions were rated on a 4-point Likert scale (1=never, $2=$ sometimes, $3=$ often, 4=always). The Cronbach's alpha value of the family interaction instrument was 0.777 . The family harmony was measured using Structure and Validity of Family Harmony Scale An Instrument for Measuring Harmony (Kavikondala et al., 2016) that has been modified by the researchers consisting of 20 statements rated on a 4-point Likert scale (1=strongly disagree, $2=$ disagree, $3=$ agree, 4=strongly agree). The family harmony questionnaire consisted of five dimensions: communication, conflict resolution, patience, identity, and quality time with family. The Cronbach's alpha value was 0.902 . The composite scores of family interactions and family harmony were categorized as low $(<60)$, moderate $(60-80)$, and high $(>80)$ (Sunarti et al., 2005).

\section{Analysis}

The obtained data were processed through editing, coding, scoring, data entry, data cleaning, data analysis, and data interpretation. Processing data was done using Microsoft Excel and for analysis using Statistical Package for Social Science (SPSS) 16. Before data collection, reliability and validity tests were carried out to examine the consistency between items in the questionnaire. Also, classical assumption tests for regression analysis were carried out including the Kolmogorov-Smirnov normality test, the heteroscedasticity scatterplots test, the multicollinearity test, and the linearity test.

Data analysis involved descriptive and inferential analyses. Descriptive analysis was used to describe: (1) distribution of family characteristics (husband's age, wife's age, husband's education length, wife's education length, husband's occupation, wife's occupation, per capita income, and family size); (2) the distribution of anxiety level scores; (3) distribution of family interaction scores; and (4) distribution of family harmony scores. Inferential analyses included (1) T-test, to analyze differences in family characteristics, anxiety levels, family interactions, and family harmony between families in the regency and city areas; (2) Pearson correlation test, to examine the relationship between family 
characteristics, anxiety levels, family interactions, and family harmony in the regency and city areas; and (3) Multiple linear regression test, to determine the effect of family characteristics variables, anxiety levels, and family interactions on family harmony in the regency and city areas.

\section{Results}

\section{Family Characteristics}

Family characteristics consisted of wife's age, husband's age, wife's education length, husband's education length, wife's occupation, husband's occupation, per capita income, and family size. The results found that the majority of wives $(81.7 \%)$ and more than half of the husbands $(66.7 \%)$ were in the middle adulthood category. However, some wives were still in early adulthood $(6.7 \%)$. Based on the t-test results, the age of the wives in Bogor Regency and Bogor City was not significantly different, with an average age of 52 years. Meanwhile, the age of the husband in Bogor Regency and Bogor City showed a significant difference $(p<0.1)$ with the average age of the husband in Bogor Regency $(57.5$ years) higher than that in Bogor City (54.3 years).

Based on the length of education, $3.3 \%$ of wives in the regency area had 6 years of education (equivalent to primary school) and 10-12 years (equivalent to high school), and the majority of wives in the city $(80 \%)$ have more than 12 years of education (equivalent to tertiary education). For the husband's length of education, more than a third of the husbands in the regency area had up to 12 years of education (equivalent to high school), and most of the wives in the city had more than 12 years of education (equivalent to tertiary education). The length of education of the research participants in the regency and city of Bogor showed a significant difference $(p<0.001)$. The length of education of the wife and husband in the city was higher than that in the regency.

Types of employment of wives and husbands varied in two areas. The majority of wives both in Bogor Regency (83\%) and Bogor City (76\%) were housewives and had no paid job. This shows that only a few wives worked in the formal sector. One-third of husbands in the regency area did not have any paid job and one in four worked as a private employee. More than half of the husbands in the city (56.7\%) worked as private employees, doctors, retirees, and consultants. More than half of families $(73.3 \%)$ were categorized as a small family. Also, one-third of families were classified as a large family. The average size of the family in the regency and city areas did not show any significant difference, ranging from 3 to 4 people.

The per capita income of the families in this study was used to indicate the prosperity level of the families. According to Badan Pusat Statistik (2018), the West Java poverty line was Rp371,376. The results showed that all families (100\%) in the city and most families $(96.75 \%)$ in the regency were in the non-poor category. The T-test results indicated that there was a significant difference between per capita income of families in two areas in which Bogor City families had a higher average per capita income of Rp5,249,000 compared to Bogor Regency families with the average per capita income of $\mathrm{Rp} 1,240,970$. 


\section{Anxiety Levels}

Anxiety level is a perception of unpleasant feelings and the results of physiological reactions. In this study, the level of anxiety was measured based on the wives' physiological and psychological conditions in the last three months. In general, more than half of families $(66.7 \%)$ had anxiety levels in the normal category $(\mathrm{M}=36.2)$. Table 1 shows half of the families in the regency $(50 \%)$ and the majority of families in the city $(83.3 \%)$ had normal levels of anxiety. Also, the results of the t-test showed that the average level of family anxiety index in the regency (38.7) was significantly higher than that in the city (33.8) $(p<0.05)$.

Table 1. Distribution of participating families by anxiety levels

\begin{tabular}{lcccccc}
\hline \multirow{2}{*}{ Category } & \multicolumn{2}{c}{ Regency } & \multicolumn{2}{c}{ City } & \multicolumn{2}{c}{ Total } \\
\cline { 2 - 7 } & $\mathrm{n}$ & $\%$ & $\mathrm{n}$ & $\%$ & $\mathrm{n}$ & $\%$ \\
\hline Normal (25-40) & 15 & 50.0 & 25 & 83.3 & 40 & 66.7 \\
Mild (40.01-55) & 14 & 46.7 & 5 & 16.7 & 19 & 31.6 \\
Moderate (55.01-70) & 1 & 3.3 & 0 & 0.0 & 1 & 1.7 \\
Severe (70.01-85) & 0 & 0.0 & 0 & 0.0 & 0 & 0.0 \\
Very severe (85.01-100) & 0 & 0.0 & 0 & 0.0 & 0 & 0.0 \\
\hline Total & 30 & 100.0 & 30 & 100.0 & 60 & 100.0 \\
Min - max & \multicolumn{2}{c}{$25.0-59.7$} & & $25.0-47.2$ & \multicolumn{2}{c}{$25.0-59.7$} \\
Mean \pm SD & \multicolumn{2}{c}{$38.7 \pm 7.6$} & \multicolumn{2}{c}{$33.8 \pm 5.8$} & & $36.2 \pm 7.2$ \\
-value & & & & $0.007 * * *$ & \\
\hline
\end{tabular}

Note. $(*)$ significant at $p<0.1,(* *)$ significant at $p<0.05,(* * *)$ significant at $p<0.001$

\section{Family Interactions}

Family interaction is a reciprocal relationship between husband and wife as well as parent and child. The results of the study showed that the family interaction scores ranged from 53.8 to 88.6 and the average score was 71.1 (Table 2). The average scores of family interactions in the regency and the city showed a significant difference $(p<0.01)$. Families in cities (74.2) had higher family interactions than families in the regency (67.9). More than half of the families in the regency $(66.7 \%)$ and the city $(83.4 \%)$ were in the medium category.

Table 2. Distribution of participating family by family interactions

\begin{tabular}{lcccccc}
\hline \multirow{2}{*}{ Category } & \multicolumn{2}{c}{ Regency } & \multicolumn{2}{c}{ City } & \multicolumn{2}{c}{ Total } \\
\cline { 2 - 7 } & $\mathrm{n}$ & $\%$ & $\mathrm{n}$ & $\%$ & $\mathrm{n}$ & $\%$ \\
\hline Low $(<60)$ & 6 & 20.0 & 1 & 3.3 & 7 & 11.7 \\
Moderate $(60-80)$ & 20 & 66.7 & 25 & 83.4 & 45 & 75.0 \\
High $(>80)$ & 4 & 13.3 & 4 & 13.3 & 8 & 13.3 \\
\hline Total & 30 & 100.0 & 30 & 100.0 & 60 & 100.0 \\
Min - max & $53.8-88.6$ & $55.3-84.1$ & $53.8-88.6$ \\
Mean \pm SD & $67.9 \pm 8.9$ & $74.2 \pm 75.7$ & $71.1 \pm 8.4$ \\
$p$-value & & \multicolumn{2}{c}{$0.003^{* * *}$} \\
\hline
\end{tabular}

Note. $(*)$ significant at $p<0.1,(* *)$ significant at $p<0.05,(* * *)$ significant at $p<0.001$

Based on the distribution of respondents' answers, wives in the regency and the city often advised their husbands (36.7\%), wives in the regency and the city help their husbands 
solve problems $(30 \%)$, wives in the regency $(50 \%)$ and the city $(53.3 \%)$ felt safe let the husband make a decision, and wives in the regency $(73.3 \%)$ and the city $(70 \%)$ stated that the husband did not rebuke his wife in front of the family if the wife did something wrong. However, there were still families in the regency (20\%) and the city $(3.3 \%)$ who had a low level of family interactions. This happened because there were $50 \%$ of wives in the regency who were upset when the husband did not grant her wishes, as many as $43.3 \%$ of wives in the regency and $26.7 \%$ of wives in the city rarely expressed affection for their husbands. The results also showed that the average index of husband-wife interactions in the city was higher (73.0) compared to husband-wife interactions in the regency (67.8).

\section{Family Harmony}

Family harmony is a feeling of satisfaction and happiness felt by family members and good relations between family members (Chuang, 2005; Lam et al., 2012). Based on the results of the study (Table 3), in general, there were two-thirds of families $(71.1 \%)$ in a high category of family harmony. However, the average score of family harmony in the city (88.4) was higher than that in the regency (81.9). This difference is reflected in parents in the city who more often encouraged their children as compared to parents in the regency, families in the city were better at resolving conflicts in the family compared to families in the regency, families in the city more often provided support to family members than families in the regency, families in the city had more frequent discussions compared to families in the regency, and families in the city were more proud of the achievement their child compared to families in the regency.

Table 3. Distribution of participating families by family harmony

\begin{tabular}{lcccccc}
\hline \multirow{2}{*}{ Category } & \multicolumn{2}{c}{ Regency } & \multicolumn{2}{c}{ City } & \multicolumn{2}{c}{ Total } \\
\cline { 2 - 7 } & $\mathrm{n}$ & $\%$ & $\mathrm{n}$ & $\%$ & $\mathrm{n}$ & $\%$ \\
\hline Low $(<60)$ & 0 & 0.0 & 1 & 3.3 & 1 & 1.7 \\
Moderate $(60-80)$ & 12 & 40.0 & 4 & 13.3 & 16 & 26.7 \\
High $(>80)$ & 18 & 60.0 & 25 & 83.4 & 43 & 71.7 \\
\hline Total & 30 & 100.0 & 30 & 100.0 & 60 & 100.0 \\
Min $-\max$ & $64.8-100.0$ & & & & $57.4-100.0$ \\
Mean \pm SD & $81.9 \pm 10.1$ & & & & \\
$p$-value & & & $0.021^{* *}$ & & \\
\hline
\end{tabular}

Note. $(*)$ significant at $p<0.1,(* *)$ significant at $p<0.05,(* * *)$ significant at $p<0.001$

More than half the families in the regency $(60 \%)$ and the city $(83.4 \%)$ had family harmony in the high category, and as many as $1.7 \%$ of families in the city had low levels of family harmony. Family harmony was represented through the statements, such as parents often contacted their children and gave encouragement, husband and wife resolved conflicts well, children remained polite with parents even when away, family members provided mutual support for each other, family members made time for family time, and parents remained to feel happy even though their child was not at home. 


\section{The Relationship between Family Characteristics, Anxiety Levels, Family Interactions, and Family Harmony}

The Pearson correlation test results (Table 4) showed the wife's education, husband's education, and per capita income were significantly negatively associated with anxiety levels. This means that the longer the education of the husband and wife and the higher the per capita income, the lower the level of anxiety of the family. Meanwhile, the wife's education, husband's education, and per capita income were significantly positively related to family interactions. This indicates that the higher the per capita income and the higher the wife and the husband's education, the better the family interactions.

Table 4. Relationship between family characteristics, anxiety levels, family interactions, and family harmony

\begin{tabular}{|c|c|c|c|}
\hline Variable & Anxiety Level & Family Interaction & Family Harmony \\
\hline Wife's age (year) & -0.181 & 0.009 & 0.031 \\
\hline Wife's education (year) & $-0.512 * *$ & $0.374 * *$ & $0.413 * *$ \\
\hline Husband's age (year) & -0.117 & -0.046 & -0.097 \\
\hline Husband's education (year) & $-0.361 * *$ & $0.409 * *$ & $0.416 * *$ \\
\hline Family size (person) & 0.032 & -0.059 & -0.135 \\
\hline Per capita income (Rp) & $-0.268 *$ & $0.317 *$ & $0.336 * *$ \\
\hline Anxiety level (index) & 1 & $-0.345 * *$ & $-0.296 *$ \\
\hline Family interaction (index) & & 1 & $0.588 * *$ \\
\hline Family harmony (index) & & & $\mathbf{1}$ \\
\hline
\end{tabular}

Note. $(*)$ significant at $p<0.1,(* *)$ significant at $p<0.05,(* * *)$ significant at $p<0.001$

The length of wife and husband's education and per capita income were significantly positively associated with family harmony. This means that the longer the education of the wife and husband and the higher the per capita income, the better the family harmony. Anxiety levels had a significant negative relationship with family interactions and family harmony. The lower the anxiety felt by the wife, the better the family interaction and family harmony.

\section{The Effect of Family Characteristics, Anxiety Levels, and Family Interactions on Family Harmony}

Multiple linear regression test was used to examine the effect of family characteristics, anxiety levels, and family interactions on family harmony. The regression model had an Adjusted R Square value of 0.333, which means that $33.3 \%$ of family harmony can be predicted by the variables in the model whereas the remaining $66.7 \%$ was explained by other variables that were not examined. The results of multiple linear regression tests (Table 5) showed that family harmony was predicted by husband-wife interactions $(\mathrm{B}=0.375, p<0.01)$ and parent-child interactions $(\mathrm{B}=0.443, p<0.05)$. This result indicates that each increase in one unit score of husband and wife interaction would raise the family harmony score of 0.375 . Also, each increase in one unit score of parent-child interaction will increase the family harmony score by 0.443 . 
Table 5. Regression analysis of family characteristics, anxiety levels, family interactions, and family harmony

\begin{tabular}{lccc}
\hline \multicolumn{1}{c}{ Variable } & Beta Unstandardized & Beta Standardized & $p$-value \\
\hline Constant & 12.778 & & 0.596 \\
Area (0=regency; 1=city) & -2.828 & -0.130 & 0.470 \\
Wife's age (year) & 0.248 & 0.156 & 0.265 \\
Wife's education (year) & 0.674 & 0.292 & 0.121 \\
Wife's job (0=no paid job; 1= have paid job) & -1.595 & -0.059 & 0.644 \\
Family size (person) & -0.059 & -0.008 & 0.951 \\
Per capita income (Rp) & 0.001 & 0.213 & 0.162 \\
Physical anxiety level (index) & -0.156 & -0.102 & 0.484 \\
Psychological anxiety level (index) & 0.239 & 0.202 & 0.229 \\
Husband-wife interaction (index) & 0.375 & 0.372 & $\mathbf{0 . 0 0 3}^{* * *}$ \\
Parent-child interaction (index) & 0.443 & 0.291 & $\mathbf{0 . 0 2 6}^{* *}$ \\
\hline F & & 3.942 & \\
$p$-value & & $0.001 * *$ & \\
Adjusted R square & & 0.333 & \\
\hline N. & & & \\
\hline
\end{tabular}

Note. $(*)$ significant at $p<0.1,(* *)$ significant at $p<0.05,(* * *)$ significant at $p<0.001$

\section{Discussion}

The results of family characteristics showed that on average, the participating husbands and wives in the regency and the city areas were in middle adulthood. Middle adulthood is an age filled with responsibilities and various roles that take up time and energy. These responsibilities include working outside the home, doing household chores, and caring for children (Santrock, 1995). Also, husband and wife must foster harmonious relationships within the family, establish effective communication between family members, maintain basic support for children, increase friendship, and readiness of parents to send-off their adult child (Herawati et al., 2018).

The length of education of husbands and wives in the city was higher than that in the regency. On average, husbands in the city did education for 16 years or equivalent to graduating from college, while husbands in the regency did education for 11 years or equivalent to not graduating from high school. Meanwhile, wives in the city had an average length of education of 15 years or equivalent to graduating from college, while wives in the regency had an average of 8.8 years or equivalent to not graduating from middle school. This difference occurs because people in the city have better access to education, better education facilities, and more qualified teachers than in the regency (Vito, Krisnani, \& Renawaty, 2016). Higher education will make someone achieve a good career and income (Rambe, 2015). Per capita income in the city and the regency showed a statistical difference. The average income in the city was Rp5,249,000 while the regency was Rp1,240,970.

The family launching stage is a stage in the family life cycle marked by the launching of the first (adult) child from home. According to Sunarti (2013), a family at this stage has critical developmental tasks, that is, providing support to children and maintaining the condition of the home as a source of support for children. When children leave home, parents especially mothers experience negative effects such as depression, identity crisis, and conflict in marriage (Hiedemann, Suhomlinova, \& O'Rand, 1998). The 
finding in this study indicates that the anxiety level reported by the mothers was classified as normal. This condition is often experienced by mothers who are ignored by their children and will not interfere with mothers in their daily activities (Carr, 1948 in Rohmaningsih, 2013). The anxiety level of mothers in the regency was higher than in the city, this is due to differences in environmental, socio-cultural conditions, and the ability of individuals to overcome problems (Twenge, 2000).

Another negative impact on parents when children leave home is identity crisis and conflict in marriage. This study found that pride in family identity was high. However, the pride of family identity in the city was higher than that of families in the regency. This is evidenced by parents in the city having a feeling of pride in children's achievements and continue to advise children compared to families in the regency. The settlement of conflicts in families in the regency and city is good enough. The results showed that most families solve problems by discussing, maintaining communication with children who leave home, and children still speak politely with parents.

Besides having a negative impact, the departure of children from home also has a positive impact that parents have time to reconnect and can channel hobbies that may have long been abandoned because of the presence of children (Dennerstein et al., 2000). The majority of husband and wife in this study reported taking time to interact with each other, some wives express affection for their husbands and help their husbands solve their problems. This is done to fulfill the task of family development at the launching stage which is to re-establish the intimacy of the relationship between husband and wife (Carter \& McGoldrick, 1980).

The results of the study found that, in general, family interactions were categorized as moderate and there were significant differences between family interactions in the city and the regency. The difference is allegedly due to differences in the length of education of the wife and husband in the city with the regency. Following Hasanah and Martiastuti (2018), husband and wife education is one aspect that influences the effectiveness and efficiency of interactions in the family. Based on the dimensions of husband-wife interaction, most families in the regency and the city had a moderate categorized husbandwife interaction. The result of the t-tests showed that husband and wife interactions in the city were higher than those in the regency. This is in line with the distribution of respondents' answers, wives in the city are more often in expressing affection to their husbands, and wives in the city are better at managing emotions so that they are not easily upset when their desires are not conceded by their husband.

The same thing is also seen in the dimensions of parent-child interaction. Most families in the regency and the city had moderate categorized parent-child interactions. However, the parent-child interaction of families in the city was higher than that of families in the regency. These results are in line with the distribution of respondents' answers, that families in the city more often express affection for their children, express disapproval of children, help children solve problems, remind children when they make mistakes, speak in good language to children, parents have more confidence in their children, and invite children to discuss to solve family problems.

The family is considered harmonious if the family condition shows a balanced relationship. Family harmony in the regency and the city was categorized high, but the average score of family harmony in the city was higher than families in the regency. When 
viewed based on dimensions, from the five dimensions of family harmony, differences in harmony between families in the regency and the city are found in the dimensions of conflict resolution, patience, and identity. In the communication dimension, and time with family has a relatively similar average. This indicates that, in general, families in the regency and the city have good communication and can spend time with family.

The correlation test results found that the husband's education, wife's education, per capita income, and family interaction were significantly positively related to family harmony. This is in line with the statement of Zung and Penning (1997) that higher education can avoid the unhappiness of marriage. High-income families will be able to meet the needs of family members so that family members feel satisfied and happy (Thohir, 2008). Family interaction has a positive relationship with family harmony. In line with Yigibalom's research (2013), poor interactions in families can lead to conflict and disharmony in the family (Dewi \& Sundhana, 2013). Also, the level of anxiety had a significant negative relationship with family harmony. The lower the level of anxiety, the better the family harmony. This is in line with Kaplan, Sadock, and Grabb (2010) which states that anxiety that lasts for a long time can disrupt every aspect of life, including social, work, and psychological aspects.

The correlation test found that the husband's education, wife's education, and per capita income of the family were significantly positively related to family interaction. This is similar to the study of Jeniu, Widodo, and Widiani (2017) that the higher a person's level of education, the easier it is to receive information so that more knowledge is possessed. This knowledge will encourage someone to discuss or give advice so that interaction in the family goes well. Besides, the correlation test also found that the length of education of husband and wife and per capita income were negatively associated with anxiety levels. This means that husbands and wives who have higher education tend to have low anxiety levels. When a child leaves the house, there is a change in the family, so the family must adjust to the changing conditions. The higher a person's education, it will be easy to accept new things and easily adjust (Sholichah \& Anjarwati, 2015). Families at the launching stage need a large enough cost for the needs of family members. In this study, most families have per capita income above the poverty line so that they can meet the needs of family members. Therefore, the family in this study has a normal anxiety level.

The results of the regression test show that family interactions which include husband-wife and parent-child interactions affected family harmony. In line with Wheatley's research (2014), high family interactions can make families harmonious. These results support the statement of Allendorf and Ghimire (2013) that family interaction is one of the determinants of marital quality. Interaction in the family can be optimized through communication between family members, establishing relationships with extended families so that family harmony can be achieved to the maximum. Harmony in the family shows that the family has a good quality of marriage. Harmony in the family can be improved through mutual understanding between husband and wife, honest, trusting, and mutual respect between family members (Azizah, 2009).

This study has limitations including the absence of data that shows the length of departure of children and length of the marriage, so it is difficult to describe clearly the level of anxiety caused by the departure of children, and family harmony related to the age 
of marriage. Also, this study cannot be generalized because it does not use random sampling techniques.

\section{Conclusion and Recommendation}

\section{Conclusion}

The average age of husbands and wives in Bogor Regency and Bogor City is in middle adulthood (41-60 years). The average length of husband and wife's education in the regency and in the city is more than 12 years. The majority of families in the regency and in the city have an average per capita income above the poverty line with a family size of small families ( $\leq 4$ people). There is a significant difference in husband's age in two areas in which husbands in the regency are older than husbands in the city whereas the age of the wife in the regency and city shows no difference. The length of the husband and wife's education in the city is higher than in the regency, and the per capita income of the family in the city is higher than that of the family in the regency.

This study found that the level of wife anxiety in the regency and city is normal. On the psychological dimension, the anxiety level in the regency is higher than that in the city. Family interactions are in the medium category. Both husband-wife and parent-child interactions in the city are better than those in the regency. Family harmony in the regency and in the city is in the high category, but the family harmony in the city is better than the family in the regency.

The longer the husband and wife's education, the higher the family income, the better the interaction and the lower the anxiety level, will result in better family harmony. Husband-wife interaction and parent-child interaction affect family harmony. This shows that the better the husband-wife and parent-child interactions, the more harmonious the family will be.

\section{Recommendation}

Based on the findings of this study, the recommendations that could be given is that the family in the launching phase needs to improve the husband-wife interaction, parentchild interaction, and optimize time with their partner. Families in the regency are suggested to be more understanding to the husband and ask the husband for advice to make important decisions in the family. Families in the city are suggested to provide opportunities for children to make decisions for themselves. Future research may want to study on the family launching stage by incorporating the reasons for the child leaving home, the duration since the child leaves the house, and testing other variables that may predict the family harmony, such as family conflict, developmental tasks attainment, husband's support, and family interaction with the environment.

For the government, it is expected to separately provide information relating to family harmony, interactions in the family, symptoms of anxiety, and provide education related to the importance of retirement investment. Also, the government needs to increase the availability of consulting services related to psychological conditions in the Integrated Health Post for Elderly (Poyandu Lansia) as a center to maintain the mental health of the launching stage families and aging families. 


\section{References}

Allendorf, K., \& Ghimire, D. J. (2013). Determinants of marital quality in an arranged marriage society. Social Science Research, 42(1), 59-70. http://dx.doi.org/10.1016/j.ssresearch.2012.09.002.

Anisa, D. (2018). Tugas perkembangan, interaksi suami-istri, dan keharmonisan pasangan lansia emptynest dan non-emptynest (Unpublished undergraduate thesis). IPB University, Bogor.

Annisa, D. F., \& Ifdil. (2016). Konsep kecemasan pada lanjut usia. Konselor, 5(2), 93-99. http://dx.doi.org/10.24036/02016526480-0-00.

Azizah, S. N. (2009). Upaya masyarakat sekitar lokalisasi dalam mempertahankan keharmonisan rumah tangga: study di Desa Kaliwungu Kecamatan Ngunut Kabupaten Tulungagung (Undergraduate thesis, UIN Maulana Malik Ibrahim, Malang, Indonesia). Retrieved from https://dokumen.tips/documents/upayamasyarakat-di-sekitaran-lokalisasi-dalam-memepertahankan-rumah-tangga.html

Badan Kependudukan dan Keluarga Berencana Nasional. (2005). Keluarga Berencana dan Kesehatan Reproduksi. Jakarta: BKKBN.

Badan Pusat Statistik. (2017). Indeks Kebahagiaan 2017. Jakarta: Badan Pusat Statistik.

Badan Pusat Statistik. (2018). Tingkat kemiskinan dan ketimpangan di Jawa Barat September 2018. Berita Resmi Statistik, Retrieved from https://jabar.bps.go.id/pressrelease/2019/01/15/739/kemiskinan-dan-ketimpangan-dijawa-barat-september-2018.html.

Beuke, C. J., Fischer, R., \& McDowall, J. (2003). Anxiety and depression: why and how to measure their separate effects. Clinical Psychology Review, 23(6), 831848. http://dx.doi.org/10.1016/s0272-7358(03)00074-6.

Carter, B., \& McGoldrick, M. (1980). The Family Life Cycle: A Framework for Family Therapy. New York City: Gardner Press.

Chuang, Y. -C. (2005). Effects of interaction pattern on family harmony and well-being: test of interpersonal theory, relational-models theory, and confusion ethics. Asian Journal of Social Psychology, 8, 272-291. http://dx.doi.org/10.1111/j.1467839X.2005.00174.x.

Dennerstein, L., Dudley, E., Guthrie, J., \& Barrett-Connor, E. (2000). Life satisfaction, symptoms, and the menopausal transition. Medscape Womens Health, 5(4), E4.

Dewi, N. R., \& Sundhana, H. (2013). Hubungan antara komunikasi interpersonal pasutri dengan keharmonisan dalam pernikahan. Journal Psikologi Udayana, 1(1), 22-31. http://dx.doi.org/10.24843/JPU.2013.v01.i01.p03.

Forgeard, M. J. C., Jayawickreme, E., Kern, M. L., \& Seligman, M. E. P. (2011). Doing the right thing: measuring wellbeing for public policy. International Journal of Wellbeing, 1, 79-106.

Hasanah, U., \& Martiastuti, K. (2018). Interaksi keluarga: Sebuah Teoritis dan Aplikatif. Depok: Karima.

Herawati, T., Kumalasari, B., Musthofa, \& Tyas, F. P. S. (2018). Dukungan sosial, interaksi keluarga, dan kualitas perkawinan pada keluarga suami istri bekerja. Jurnal Ilmu Keluarga dan Konsumen, $11(1), \quad 1-12$. http://dx.doi.org/10.24156/jikk.2018.11.1.1. 
Herry, E. (2012). Tingkat kecemasan, dukungan sosial, dan mekanisme koping terhadap kelentingan keluarga pada keluarga dengan TB paru-paru di Kecamatan Ciomas Bogor (Undergraduate thesis, IPB University, Bogor, Indonesia). Retrieved from https://repository.ipb.ac.id/handle/123456789/48176

Hiedemann, B., Suhomlinova, O. \& O'Rand, A. (1998). Economic independence, economic status, and empty nest in midlife marital disruption. Journal of Marriage and the Family, 60(1), 219-231. http://dx.doi.org/10.2307/353453.

Hisbullah, M. (2007). Pengaruh tingkat kecemasan spiritual terhadap keharmonisan rumah tangga pada suami-istri di Desa Selokbesuki Kecamatan Sukodono Kabupaten Lumajang (Undergraduate thesis Universitas Islam Negeri, Malang, Indonesia). Retrieved from

Hurlock, E. B. (1980). Psikologi Perkembangan: Suatu Pendekatan Sepanjang Rentang Kehidupan. Jakarta: Gramedia.

Jeniu, E., Widodo, D. \& Widiani, E. (2017). Hubungan pengetahuan tentang autism dengan tingkat kecemasan orang tua yang memiliki anak autisme di Sekolah Luar Biasa Bhakti Luhur Malang. Nursing News, 2(2), 32-42.

Kaplan, H. I., Sadock, B. J., \& Grabb, J. A. (2010). Kaplan-Sadock Sinposis Psikiatri Ilmu Pengetahuan Perilaku Psikiatri Klinis. Tangerang: Binarupa Aksara.

Kavikondala, S., Stewart, S. M., Ni, M. Y., Chan, B. H., Lee, P. H., Li, K. K., McDowell, I., Johnston, J. M., Chan, S. S., Lam, T. H., Lam, W. W., Fielding, R., \& Leung, G. M. (2016). Structure and validity of family harmony scale: an instrument for measuring harmony. Psychological Assessment, 28(3), 307-318. http://dx.doi.org/10.1037/pas0000131.

Lam, W. W. T., Fielding, R., McDowell, I., Johnston, J., Chan, S., Leung, G. M., \& Lam, T. H. (2012). Perspective on family health, happiness and harmony (3H) among Hong Kong Chinese people: a qualitative study. Health Education Research, 27(5), 767-779. http://dx.doi.org/10.1093/her/cys087

Lestari, R., Wihastuti, T. A., \& Rahayu, B. F. (2.013). Hubungan tingkat kecemasan dengan tingkat kemandirian activties of daily living (ADL) pada lanjut usia di Panti Werdha. Jurnal Ilmu Keperawatan, 1(2), 128-134.

Lovibond, S. H., \& Lovibond, P. F. (1995). Manual For the Depression Anxiety \& Stress Scale. Sydney: Psychology Foundation.

McCubbin, H. (1988). Family Stress, Coping, and Health Project. USA: Burgess International Group, Inc.

Mu'arifah, A. (2005). Hubungan kecemasan dan agresivitas. Humanitas: Indonesian Psychological Journal, 102-111. http://dx.doi.org/10.26555/humanitas.v2i2.319.

Nancy, M. N., Wismanto, Y. B., \& Hastuti, L. W. (2104). Hubungan nilai dalam perkawinan dan pemaafan dengan keharmonisan keluarga. Psikodimensia, 13(1), 8497. http://dx.doi.org/10.24167/psiko.v13i1.280.

Pangaribuan, L. (2016). Kualitas komunikasi pasangan suami istri dalam menjaga keharmonisan perkawinan. Jurnal Simbolika, 2(1). http://dx.doi.org/10.31289/simbollika.v2i1.214.

Puspitawati, H. (2013). Pengantar Studi Keluarga. Bogor: IPB Press. 
Rambe, Y. (2015). Pengaruh interaksi dan pola pengambilan keputusan keluarga terhadap kesejahteraan subjektif keluarga suami istri bekerja (Undergraduate thesis, IPB University, Bogor, Indonesia). Retrieved from https://repository.ipb.ac.id/handle/123456789/83087

Rasmun, N. M. (2004). Stres, Koping, dan Adaptasi. Jakarta: CV Sagung Seto.

Rohmaningsih, N. (2013). Hubungan antara kualitas tidur dengan tingkat kecemasan studi pada mahasiswa/i angkatan 2011 Program Studi Pendidikan Dokter Fakultas Kedokteran Universitas Diponegoro (Undergraduate thesis, Universitas Diponegoro, Semarang, Indonesia). Retrieved from http://eprints.undip.ac.id/44110/

Santrock, J. (1995). Life Span Development (5th ed.). Jakarta: Erlangga.

Sari, D. P., \& Puspitawati, H. (2014). Family conflict and harmony of farmers family. Journal of FamilySciences, 2(1), 28-41. http://dx.doi.org/10.29244/jfs.2.1.28\%20$\% 2041$.

Septiana, V. S., Krisnatuti, D., \& Simanjuntak, M. (2011). Faktor suku dalam pola komunikasi penyesuaian suami istri, dan keharmonisan keluarga. Jurnal Ilmu Keluarga dan Konsumen, 7(1), 1-9. http://dx.doi.org/10.24156/jikk.2014.4.7.1.1

Sholichah, N., \& Anjarwati, R. (2015). Hubungan tingkat pendidikan dengan tingkat kecemasan wanita usia 40-50 tahun dalam menghadapi menopause. Jurnal Komunikasi Kesehatan, 6(20).

Sunarti, E. (2013). Ketahanan Keluarga. Bogor: IPB Press.

Sunarti, E. Tati, A. S. N., Noorhaisma, R., \& Lembayung, D. P. (2005). Pengaruh tekanan ekonomi keluarga, dukungan sosial, kualitas perkawinan, pengasuhan, dan kecerdasan emosi anak terhadap prestasi belajar anak. Media Gizi dan Keluarga, 29(1), 34-40.

Thohir, U. F. (2018). Korelasi pendapatan ekonomi dan kedewasaan pasangan terhadap keharmonisan rumah tangga pelaku pernikahan di bawah umur di Dewa Wedusan, Tiris, Probolinggo. Asy-Syari'ah, 1(1).

Triniad, D. R., Chou, C. P., Unger, J. B., Johnson, C. A., \& Li, Y. (2003). Family harmony as a protective factor against adolescent tobacco and alcohol use in Wuhan, China. Substance Use and Misuse: Institute of Health Promotion and Disease Prevention Research, 38(8), 1159-1171.

Tsania, N., Sunarti, E., \& Krisnatuti, D. (2015). Karakteristik keluarga, kesiapan menikah istri, dan perkembangan anak usia 3-5 tahun. Jurnal Ilmu Keluarga dan Konsumen, 8(1), 28-37. http://dx.doi.org/10.24156/jikk.2015.8.1.28.

Twenge, J. M. (2000). The age of anxiety? The birth cohort change in anxiety and neuroticism, 1952-1993. Journal of Personality and Social Psychology, 79(6), 1007-1021. http://dx.doi.org/10.1037/0022-3514.79.6.1007.

Vito, B., Krisnani, H., \& Renawaty, R. (2016). Kesenjangan pendidikan desa dan kota. Prosiding KS: Riset \& PKM, 2(2), 147-300.

Waldinger, R. J., \& Schulz, M. S. (2006). Linking hearts and minds in couple interaction: intentions, attributions, and overriding sentiments. Journal of Family Psychology, 20(3), 494-504. http://dx.doi.org/10.1037/0893-3200.20.3.494.

Wheatley, D. (2014). Travel-to-work and subjective well-being: a study of UK dual career households. Journal of Transport Geography, 39(C), 187-196. http://dx.doi.org/10.1016/j.jtrangeo.2014.07.009. 
Yigibalom, L. (2013). Peranan interaksi anggota keluarga dalam upaya mempertahankan harmonisasi kehidupan keluarga di Desa Kumuluk Kecamatan Tium Kabupaten Lanny Jaya. Acta Diurna, 2(4).

Yunistiati, F., Djalali, M. A., \& Farid, M. (2014). Keharmonisan keluarga, konsep diri dan interaksi sosial remaja. Persona: Jurnal Psikologi Indonesia, 3(1), 71-82. http://dx.doi.org/10.30996/persona.v3i01.371.

Zung, W. W. (1971). A rating instrument for anxiety disorders. Psychosomatics, 12(6), 371-379. http://dx.doi.org/10.1016/S0033-3182(71)71479-0.

Zung, W., \& Penning, M. J. (1997). Marital instability after midlife. Journal of Family Issues, 18(5), 459-478. http://dx.doi.org/10.1177/019251397018005001. 